Chirurgia (2021) 116: 109-116

No. 1, January - February

Copyright@ Celsius

\title{
Cutaneous and Inguinal Lymph Nodes Metastases Disseminated from an Endometrial Serous Carcinoma - Case Report and Literature Review
}

\author{
Laura Rebegea ${ }^{1,2}$, Ana-Maria Ilie ${ }^{1}$, Anca Neagu $^{2}$, Dorel Firescu ${ }^{1,3}$, Georgiana Bianca Constantin ${ }^{2}$, Rodica Bîrlă $\breve{4,5}^{, *}$, \\ Xenia Bacinschi ${ }^{3}$, Cristina Serban ${ }^{1,2}$
}

"'Department of Oncology, Sf. Ap. Andrei” Emergency Clinical Hospital Galati, Romania

2"Dunarea de Jos" University, Faculty of Medicine and Pharmacy, Galati, Romania

${ }^{3}$ General Surgery II Clinic,"Sf. Ap. Andrei” Emergency Clinical Hospital, Galati, Romania

${ }^{4}$ Center of Excellence in Esophageal Surgery, "Sf. Maria" Clinical Hospital, Bucharest, Romania

${ }^{5}$ Carol Davila University of Medicine and Pharmacy, Bucharest, Romania

${ }^{*}$ Corresponding author:

Rodica Birla, MD

General and Esophageal Surgery Department

Center of Excellence in Esophageal Surgery

Sf. Maria Clinical Hospital, Bucharest,

Romania

E-mail: birlarodica@ahoo.com

\section{Rezumat \\ Metastaze cutanate cu punct de plecare carcinom seros endometrioid - studiu de caz și discuția datelor din literatură}

Metastazele cutanate cu punct de plecare cancer endometrial sunt rare, neobişnuite. Prezentăm cazul unei paciente în vârstă de 70 ani, diagnosticată în 2018 cu carcinom seros endometrial G3. La 18 luni de la intervenția chirurgicală se prezintă cu determinări secundare inghinale bilaterale şi cutanate, biopsiate şi se efectuează teste IHC. CT TAP nu evidențiază leziuni secundare sau recidivă locoregională. Prezentăm tratamentele efectuate şi evoluția cazului şi discutăm date despre epidemiologie, biologie moleculară, opțiuni terapeutice şi managementul leziunilor locale şi avansate. Apariția leziunilor secundare cutanate se asociază cu prognostic nefavorabil, iar opțiunile terapeutice se limitează la chimioterapie şi radioterapie paliativă.

Cuvinte cheie: carcinom seros, endometru, metastaze cutanate

\section{Abstract}

Cutaneous metastases from endometrial cancer are rare and unusual. This is the case of a 72 years old female patient, 
diagnosed in 2018 with G3 endometrial serous carcinoma (ESC). At 18 months from the surgical intervention, the patient developed bilateral inguinal lymph nodes metastases and skin secondary lesions; histological and immunohistochemical tests were performed. Computed tomography scan did not indicate visceral secondary lesions, local or regional relapses. We present the treatment practiced, the case's evolution and we discuss about epidemiology, molecular biology, treatment options and management of advanced and local lesions. The appearance of skin metastases in theses cases is associated with poor prognosis and treatment options are limited to palliative chemotherapy and radiotherapy.

Key words: serous carcinoma, endometrium, cutaneous metastases

\section{Introduction}

The endometrial serous carcinoma (ESC) represents only 5-10 \% of all endometrium malignancies, being an aggressive form of it. Hendrickson et al., in 1982 recognized ESC as a distinct subtype of endometrium cancer and described it as being histological similar with ovarian serous carcinoma (1). ESC is characterized by mutations at tumoral level: p53 gene and amplification of HER2neu gene. Lymphovascular invasion is frequent and metastases are present in $36 \%$ of cases without myometrial invasion, $50 \%$ of patients with less than $50 \%$ myometrial invasion and $40 \%$ of patients with more than $1 / 2$ myometrial invasion $(2,3)$. ESC presents an increased rate of metastasis at the epiploon level. Data from literature describe, until now, $0.8 \%$ incidence of skin metastases from ESC. If in other neoplastic sites, like lung, and respective breast, the incidence of skin metastases are $1.7-3.1 \%$ and respective, $23.9 \%$, for endometrial cancer the skin metastases incidence is very low $(4,5)$. The prognosis is poor, with a median survival varying between 4 and 12 months from diagnosis's moment. Therapeutic options include palliative chemotherapy (CMT) and radiotherapy (EBRT). The mainly influencing survical factor is the time between diagnosis and the appearance of skin and lymphatic metastases (6).

\section{Case Report}

We present the case of a 72 years old female patient, from rural area, having cardiac personal pathological history with high blood pressure under treatment, diagnosed with endometrial neoplasia in 2018; the histological exam revealed a serous carcinoma poor differentiated, G3. Preoperatory, she had no lymph nodes lesions. After surgery (which was practiced in another medical unit), in June 2018 (total hysterectomy with bilateral anexectomy was staged pT1aNxMx and histology revealed endometrioid adenocarcinoma (ADK). After the operation, the patient was not monitorized. After more than one year, in December 2019, the patient came in our Medical Oncology Department and performed an computed tomography scan (CT) with venous contrast, for thoracic, abdominal and pelvis areas, which revealed multiple lymph nodes disseminations: lateral of aorta artery, anterior and posterior of cava vein $(10 / 24 \mathrm{~mm})$, left common iliac, external bilateral iliac, bilateral inguinal $(16 / 18 \mathrm{~mm})$. The following were also described: a left inguinal iodophilic lesion of $48 / 72 \mathrm{~mm}$, in subcutaneous cellular tissue, solid nodular iodophilic lesion, $30 \mathrm{~mm}$ diameter, situated in prepubic subcutaneous cellular tissue (Fig. 1). No visceral secondary lesions.

The clinical exam revealed cutaneous tumoral masses disseminated at the level of inferior abdominal wall and hypogastrium which are spontaneously bleeding, performance index (IP) ECOG (Eastern Cooperative Oncology Group), IP=2 (Fig. 2).

For the histopathological examination, a biopsy was taken from a left inguinal lymph 


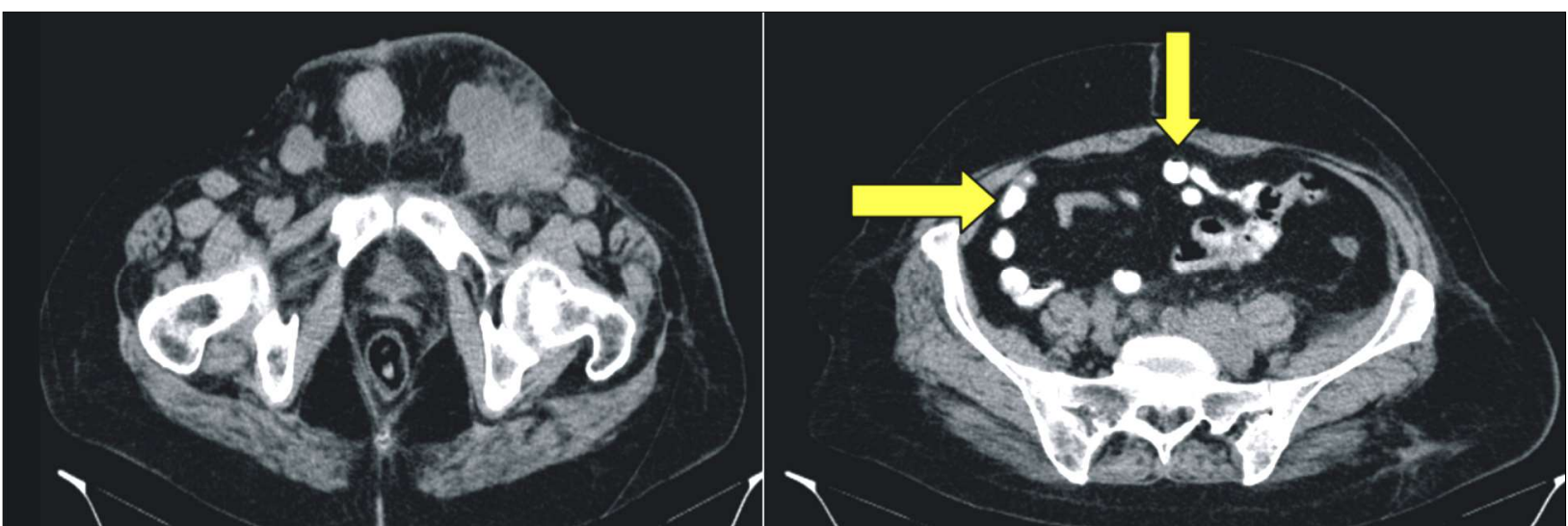

Figure 1. CT scan that showed multiple lymphadenopathies

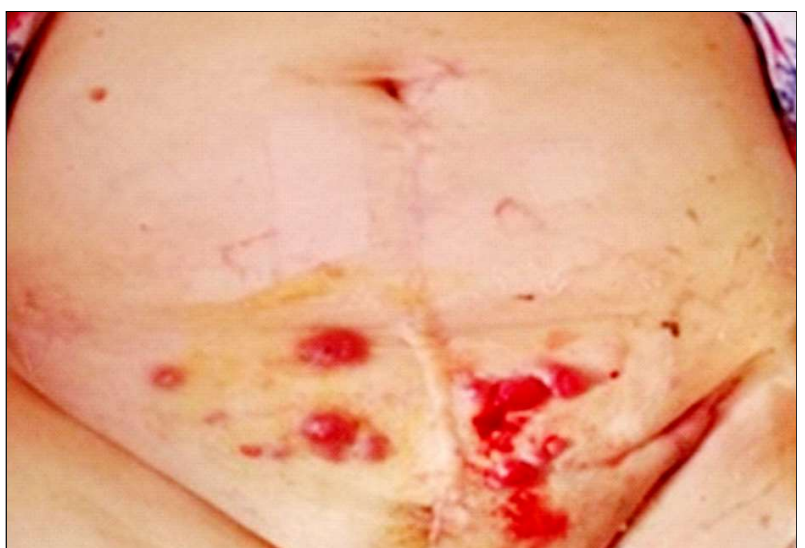

Figure 2. Cutaneous tumoral masses

node and on Hematoxylin-Eosin (HE) stained tissue sections, a fragment of connective and adipose tissue, with blood vessels, having carcinomatous infiltration was observed. The tumoral cells are arranged in cords, islets or are forming papillae (Figs. 3, 4), they have large, hyperchromatic, atypical nuclei, prominent nucleoli and scant cytoplasm (Fig. 5) and intense mitotic activity (Fig. 6).

For immunohistochemistry (IHC) tests, there were used the following monoclonal mouse anti-human antibodies: Cytokeratin 7 (CK7) [clone OV-TL12/30, ready to use (RTU)], p53 Protein (clone DO-7, RTU), WT1 Protein (clone 6F-H2, RTU), Ki-67 Antigen (clone MIB-1, RTU), Cytokeratin 20 (CK20), (clone KS20.8, RTU), Estrogen Receptor a (ER) (clone EP1, RTU), Progesterone Receptor (clone PgR 636, RTU) and the mono-

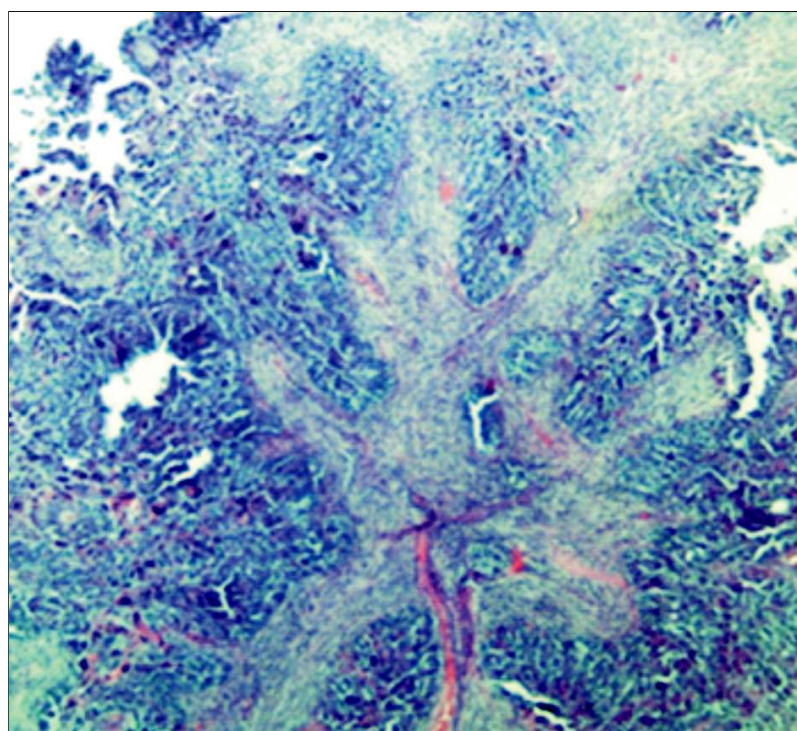

Figure 3. Microscopically appearance - the tumor shows a papillary pattern with irregular papillae. HE staining, $x 40$

clonal rabbit anti-human antibody p16 (clone RBT-p16, RTU). The results were the following: CK7 showed diffuse membranous positivity and focal cytoplasmic positivity, p53 Protein had nuclear positivity, in the majority of tumoral cells, WT1 was diffusely positive in the membranes of the tumoral cells, but showed only focal nuclear positivity and CK20, ER, PR, p16 antibodies were negative in the tumoral cells (Fig. 7 ). Nuclear expression of Ki67 proliferation index was detected in approximately $70 \%$ of the tumoral cells (Fig. 8).

The correlation between the histopathological aspects, the IHC results and the 


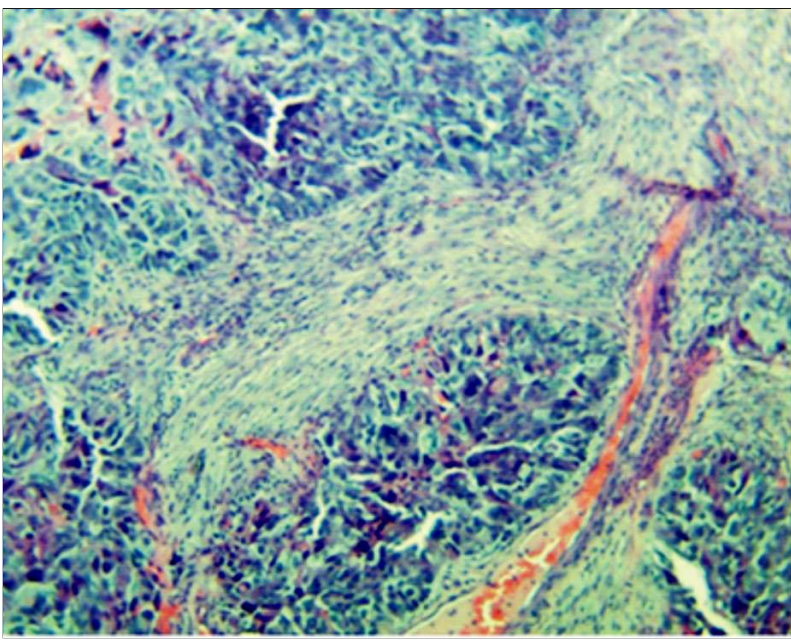

Figure 4. High-grade serous carcinoma: islets of tumoral cells, the epithelium resemble that of Fallopian tubes, with cytonuclear atypia, hyperchromatic and pleomorphic nuclei. HE staining, $x 100$

clinical data established the diagnosis of metastasis of high-grade serous carcinoma, probably with endometrial starting point.

Biological, the patient presents grade 2 secondary anemia, Staphyloccocus aureus MRSA infection for which she received antibiotic treatment conforming with antibiogram, $\mathrm{II}^{\text {nd }}$ grade antalgic treatment and anticoagulant treatment. In Oncological Committee it was recommended palliative CMT and EBRT. Four cycles of CMT with Carboplatin and Paclitaxel were performed; due to the digestive side effects, the cytostatic dose was decreased with $25 \%$, at the $4^{\text {th }}$ CMT cycle.

After signing the informed consent, we practiced a palliative EBRT, in conformational technique, with $10 \mathrm{MV}$ photons, total dose $\mathrm{TD}=30 \mathrm{~Gy} / 10$ fractions /14 days, dose per fraction $=300 \mathrm{cGy}$ on nodal target volume involving common, internal, external and obturator iliac lymph nodes. EBRT was well tolerated.

In present, the patient performs CMT and CT scan for evaluation, which indicate dimensional decreasing of common external iliac lymphnodes and left external iliac lymphnodes, without lung secondary lesions. The patient still has a good ECOG IP.

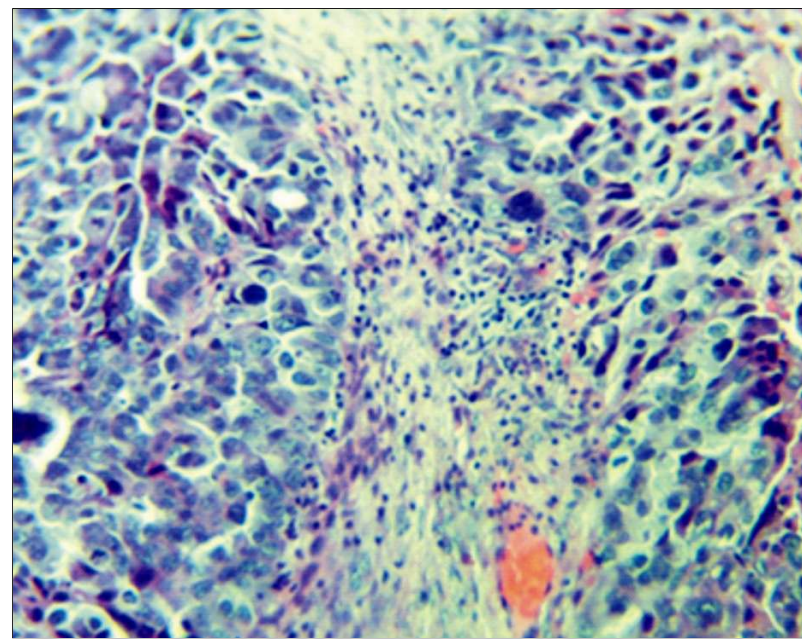

Figure 5. Tumoral cells have large atypical nuclei, with prominent nucleoli, scant cytoplasm. HE staining, 200x

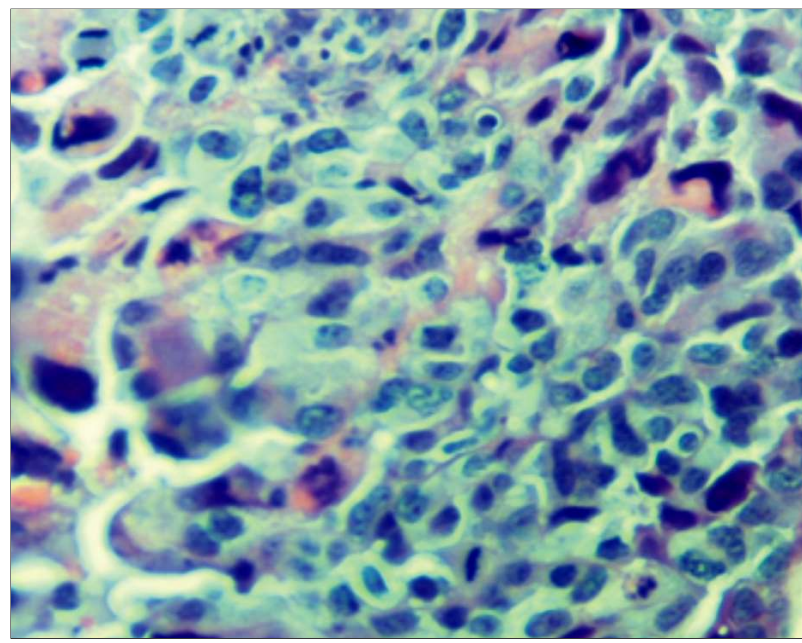

Figure 6. Tumoral cells have a high mitotic activity; there are 3 mitotic figures in this HPF. HE staining, $x 400$

\section{Discussions}

ESC represents 5-10\% of endometrial malignancies and it's an aggressive form of it. There were published only 26 cases until 2014. The first type of endometrial cancer represents $80 \%$ of the total number of cases associated with endometrioid component, diagnosed at young women with positive receptors for estrogens and progesterone, and with no history of estrogen exposure and 


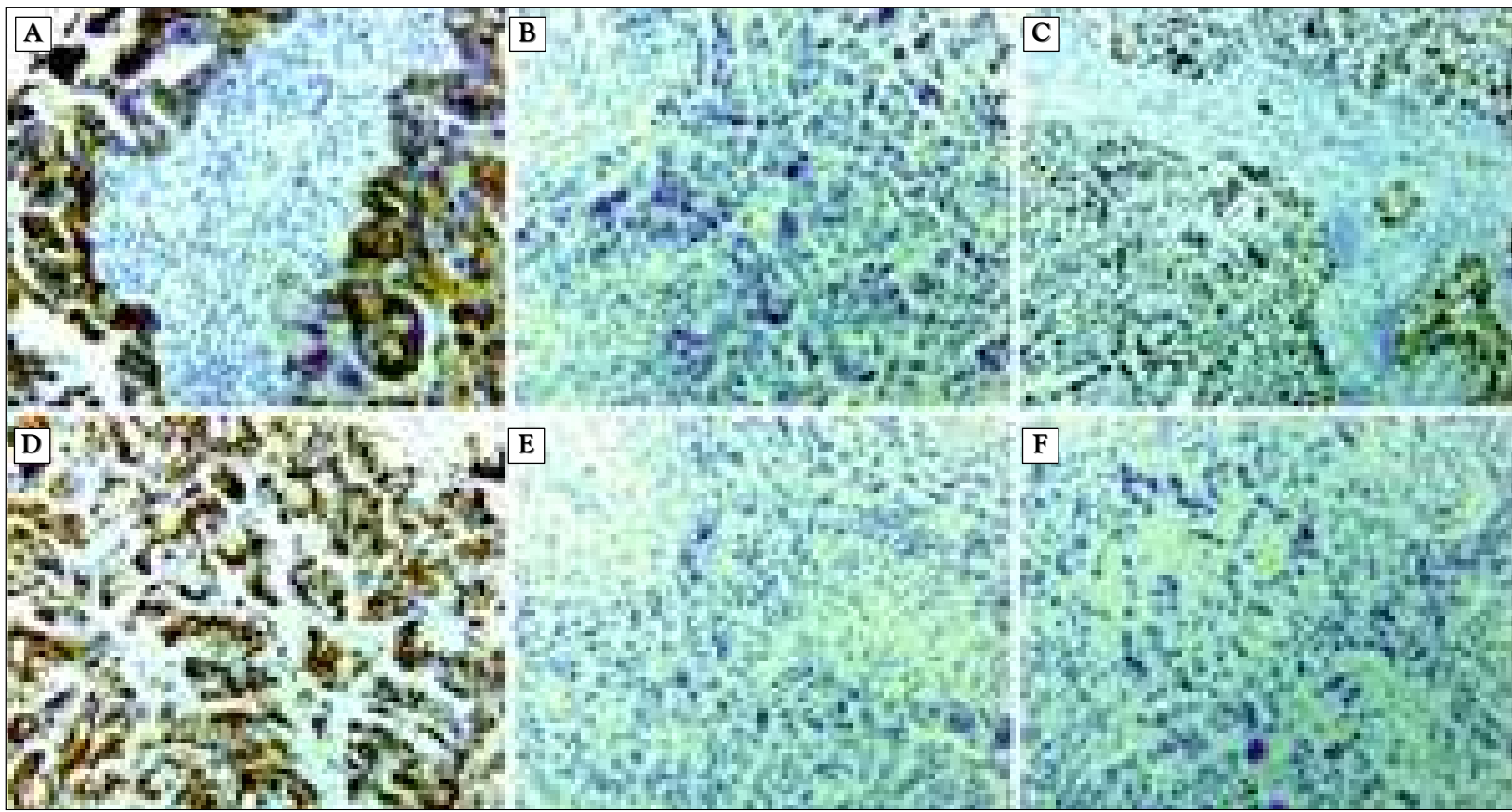

Figure 7. IHC features of the tumoral cells. (A) Intensely positive membranous immunostaining for anti-CK7 antibody, x200;

(B) Negative membranous and cytoplasmic immunostaining for anti-CK20 antibody, 200x; (C) Intensely positive nuclear staining for anti-p53 antibody, 100x; (D) Diffuse membranous positivity of WT1, 200x; (E) Negative IHC reaction of tumor cells to ER, 200x; (F) p16 negativity of the tumoral cells, 200x

mutations of KRAS and PTEN (7-9).

The second type is associated with serous component with clear cell or endometrioid component, IIIrd grade, absence of estrogen and progesterone receptors is diagnosed in older women, with reduced expression of E-cadherin, aneuploidy, p53 mutations and

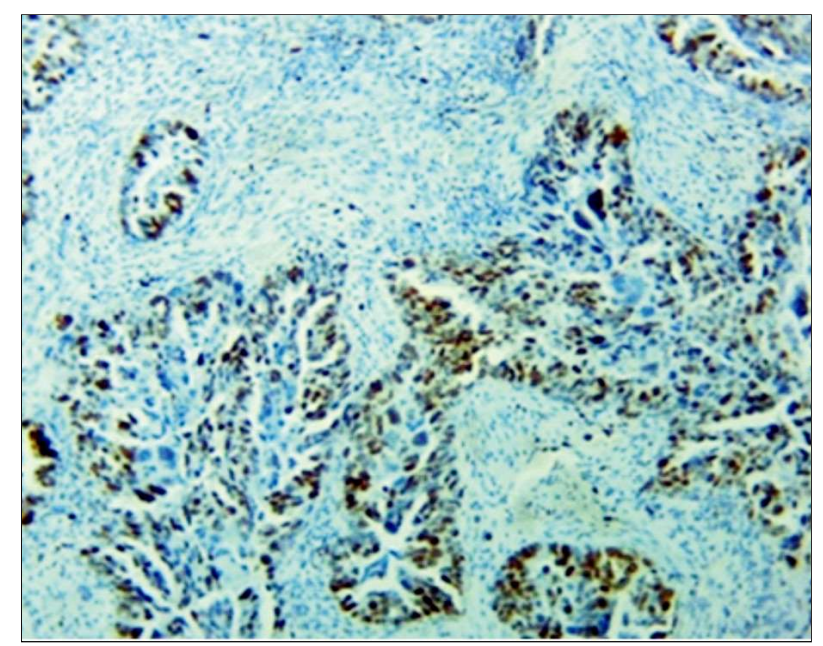

Figure 8. An approximately $70 \%$ Ki67 positivity index. Immunostaining for Ki67 antibody, 100x
HER2neu supra-impression. But 20\% of ESC are completely negative for p53 (10). They are more aggressive than type I and also have more unfavorable prognosis; the median occurrence age is 63; it is not mediated by hormones and might be recognized by premalignant lesions.

Because the tumor has an aggressive behavior, an adjuvant treatment and primary surgical staging are required in most of the cases. Even if randomized trials have failed to show any survival benefits associated with systematic lymph node dissection in endometrial cancer, the detection of nodal dissemination does affect staging, prognosis and possibly the postoperative treatment decisions (11). Besides, in 1988, the International Federation of Gynecology and Obstetrics (FIGO) changed the staging system for endometrial cancer from clinical staging to surgical staging (12). The American College of Obstetricians and Gynecologists (ACOG) committee suggested that adjuvant therapy should only be limited to patients with positive lymph nodes (13). 
Venigalla et al. used the National Cancer Database in order to analyze 7250 patients diagnosed with serous uterine carcinoma, clear cell carcinoma and carcinosarcoma who underwent histerectomies between 2010-2013. Pelvic lymph nodes dissection was associated with a decreased risk of death in all the histologic subtypes (14). Other authors consider that a trully therapeutic lymph node dissection should be performed above the renal veins and likely to the scalene nodal basins, otherwise there are no survival benefits (11).

The surgical management in these cases has changed over time. The role of the lymph node dissection is still a matter of debate from the survival benefits point of view. Still, the lymph node dissection may help identify patients with metastatic dissemination, who may benefit from adjuvant therapy and it may also eradicate metastatic disease (15).

According to a risk stratification system from Mayo Clinic, Rochester, Minnesota, USA, low-risk patients can be adequately treated removing the uterus and the adnexa alone, without significantly compromising survival (16). The need to perform lymph node dissection is based on the tumor characteristics (the histological type, FIGO grade, the tumor's diameter and depth of the myometrial invasion) determined at frozensection analysis (17). There are no generally accepted scoring systems based on preoperative and operative parameters that can be used to reduce the rate of unnecessary lymphadenectomy (18).

After decades of debate, we still do not have convincing data demonstrating a therapeutic role of lymph node dissection in endometrial carcinomas (19).

Taking into account that the lymphatic spread is relatively unusual, we should direct our efforts to identify patients who may potentially benefit from lymph node dissection.

From the molecular pathogenesis point of view, the endometrial cancer, type I and II are different. The first type is frequently associated with KRAS and PTEN mutations and other inconsistency of defense mechanisms. The second type ESC are associated with aneuploidy and overexpression of HER2/NEU, cyclin, claudin 3 and 4 ; there were also associated with mutation's expression in TP53 and other proteins (7).

From the total number of cases, $52-70 \%$ of cases with IInd type endometrial cancer, present extra-uterus extension at the surgery moment, comparing with only $4.6 \%$ in low grade tumors.

In endometrial ADK, the overexpression of HER2 is found in 4-69\% of cases and it is the most frequent in high grade tumors. ESC has the highest rate of overexpression of HER2 comparative with other endometrial neoplasia.

Many studies showed that HER2 receptor is over expressed in $18-80 \%$ of cases, but this proportion is dependent on IHC technique.

This gene with overexpression was found in afro-american women, comparative with Caucasian women, these having also a lower survival rate. HER2 overexpression can be considered an important molecular target in ESC treatment (20).

$\mathrm{P} 13 \mathrm{~K} / \mathrm{AKT} / \mathrm{m}$ TOR inhibitors path way in gynecological cancers was studied by a small number of clinical trials. In 2011 one clinical trial performed by the National Cancer Canadian Institute reported favorable results after therapy with Temsirolimus (inhibitor $\mathrm{m}$ TOR. in patients with advanced endometrial neoplasia (21).

Other phase II randomised trail, comparing Carboplatin, Paclitaxel and Bevacizumab with Carboplatin, Paclitaxel, Temsirolimus or Ixabepilone, Carboplatin and Bevacizumab in ongoing (22).

In endometrial cancer, VEGF-A expression is an important prognostic indicator. It is considered that overexpression of this monoclonal agent indicates an unfavorable prognosis, an advanced disease stage, lymphovascular invasion, lymph nodes invasion and p53 override (23).

Claudin 3 and 4 are considered markers for biological agressivity. In a study that included 20 probes of ESC, Clostridium perfringens toxin (CPE) receptors were indentified in $100 \%$ of cases, with significantly high values 
in metastatic serous carcinoma probes, comparative with probes collected from primary tumor. Thus recurrent ESC or ESC which is not responding at standard therapy might be feasible for CPE based therapies (24).

Elective treatment for ESC assumes surgical staging by most complete laparotomy, laparoscopy and maximal cytoreduction to complete excision. Complete surgical resection is total hysterectomy with bilateral oophorectomy, salpingectomy, pelvic and para-aortic lymph node dissection, complete omentectomy and peritoneal lavage with biopsy in selected cases (25).

For patients with limited residual disease, an option can be adjuvant CMT with Carboplatin and Paclitaxel and vaginal brachytherapy. Patients with advanced or recurrent disease who do not respond at CMT should benefit by genomic testing in order to follow target therapy (7).

ESC is similar with ovarian cancer and this is sustained by the intra-abdominal evolution of disease that may lead to relapsing. This is the reason why the chemotherapy regimens and therapeutic management are similar in ovarian cancer with advanced ESC.

The five years survival rate in endometrioid $\mathrm{ADK}$ varies between 80 and $90 \%$ for stage I patients, but only $50-80 \%$ of stage I ESC patients present similar survival rates $(1,27-$ $30)$. Taking into account the negative prognosis, an aggressive therapeutic management is strongly recommended.

\section{Conclusions}

The molecular biology and pre-neoplastic lesions differ between ADK endometrioid and ESC. The elective treatment for ESC involves radical surgery or maximal cytoreduction when it is not possible a complete intervention and therapeutic options in metastatic disease are palliative chemotherapy and radiotherapy.

The continuing debate about the role of lymph node dissection will probably end only when molecularly guided imaging or new biologic therapy become available in order to identify and treat systemic metastatic disease.
The presented case is rare in the literature, skin and lymph node metastases being extremely rare in ESC. The mainly influencing survival factor is the time between the diagnosis and the appearance of cutaneous and lymph node metastases.

\section{Conflicts of Interests}

The authors declare no conflicts of interests.

\section{Ethics of Approval}

We obtained the written agreement of the patient for publishing the case and also the written agreement of our Ethics Commitee.

\section{References}

1. Nickles Fader A, Boruta D, Olawaiye AB, Gehrig PA. Updates on uterine papillary serous carcinoma. Obstetrics and Gynecology 2014;4(6):647-657

2. Zheng W, Cao P, Zheng M, Kramer EE, Godwin TA. p53 overexpression and $\mathrm{Bcl}-2$ persistence in endometrial carcinoma: comparison of papillary serous and endometrioid subtypes. Gynecol. Oncol. 2008;61(2):167-174

3. Jongen VH, Briët JM, de Jong RA. Aromatase, cyclooxygenase 2, HER-2/neu, and p53 as prognostic factors in endometrioid endometrial cancer. Int. J. Gynecol. Cancer 2009;19(4):670-676

4. Marcoval J, Penín RM, Llatjós R, Martínez-Ballarín I. Cutaneous metastasis from lung cancer: retrospective analysis of 30 patients. Australas J Dermatol. 2012:53:288-290

5. Elit L, Lukka H, Friedman E. Cutaneous metastasis of papillary serous uterine cancer. Gynecol Oncol. 2001;82:208-211

6. Cormio G, Capotorto M, Di Vagno G, Cazzolla A, Carriero C, Selvaggi L. Skin metastases in ovarian carcinoma: a report of nine cases and a review of the literature. Gynecol Oncol. 2003;90:682685

7. Black JD, English DP, Roque DM, Santin AD. Targeted therapy in uterine serous carcinoma: an aggressive variant of endometrial cancer. Womens Health (Lond. 2014;10(1):45-57

8. Lax SF, Pizer ES, Ronnett BM, Kurman RJ. Comparison of estrogen and progesterone receptor, Ki-67, and P53 immunoreactivity in uterine endometrioid carcinoma and endometrioid carcinoma with squamous, mucinous, secretory, and ciliated cell differentiation. Hum. Pathol. 1998;29(9):924-931

9. Rebegea L, Firescu D, Dumitru M, Patrascu A. Skin spiradenocarcinoma- case presentation. Rom J Morphol Embryol 2016; 57(1):327-330

10. Sherman ME. Theories of endometrial carcinogenesis: a multidisciplinary approach. Modern Pathol. 2000;13(3):295-308

11. Basaran D, Bruce S, Aviki E, Alektiar K, Abu-Rustum N, Lietao M et al. Sentinel lymph node mapping alone compared to more extensive lymphadenectomy in patients with uterine serous carcinoma. Gynecologic oncology 2019;156(1):70-76

12. Mikuta JJ. International Federation of Gynecology and Obstetrics staging of endometrial cancer 1988. Cancer. 1993;71:1460-1463

13. American College of Obstetricians and Gynecologists ACOG practice bulletin, clinical management guidelines for obstetriciangynecologists, number 65, August 2005: Management of endome- 
trial cancer. Obstet Gynecol. 2005;106:413-425

14. Venigalla S, Chowdhry AK, Shalowitz DI. Survival implications of staging lymphadenectomy for non-endometrioid endometrial cancers. Gynecol. Oncol. 2018;149:531-538

15. Bogani G, Dowdy SC, Cliby WA, Ghezzi F, Rossetti D, Marian A. Role of pelvic and para-aortic lymphadenectomy in endometrial cancer: current evidence. J Obstet Gynaecol Res. 2014;40(2):301-311

16. Dowdy SC, Borah BJ, Bakkum-Gamez JN, et al. Prospective assessment of survival, morbidity, and cost associated with lymphadenectomy in low-risk endometrial cancer. Gynecol Oncol. 2012;127:5-10

17. Kumar S, Mariani A, Bakkum-Gamez JN, et al. Risk factors that mitigate the role of paraaortic lymphadenectomy in uterine endometrioid cancer. Gynecol Oncol. 2013;130:441-445

18. Todo Y, Okamoto K, Hayashi M. A validation study of a scoring system to estimate the risk of lymph node metastasis for patients with endometrial cancer for tailoring the indication of lymphadenectomy. Gynecol Oncol. 2007;104:623-628

19. Ayeni TA, Bakkum-Gamez JN, Mariani A, et al. Comparative outcomes assessment of uterine grade 3 endometrioid, serous, and clear cell carcinomas. Gynecol Oncol. 2013;129:478-485

20. Morrison C, Zanagnolo V, Ramirez N. HER-2 is an independent prognostic factor in endometrial cancer: association with outcome in a large cohort of surgically staged patients. J. Clin. Oncol. 2006; 24(15):2376-2385

21. Oza AM, Elit L, Tsao MS. Phase II study of temsirolimus in women with recurrent or metastatic endometrial cancer: a trial of the NCIC Clinical Trials Group. J. Clin. Oncol. 2011;29(24):3278-3285

22. Aghajanian C, Filiaci V, Dizon DS, Carlson JW, Powell MA, Alvarez Secord A et al. Paclitaxel, Carboplatin, and Bevacizumab or
Paclitaxel, Carboplatin, and Temsirolimus or Ixabepilone, Carboplatin, and Bevacizumab in Treating Patients With Stage III, Stage IV, or Recurrent Endometrial Cancer. Gynecol. Oncol. 2018; 150(2):274-281

23. Mazurek A, Pierzynski P, Kuc P. Evaluation of angiogenesis, $p-53$ tissue protein expression and serum VEGF in patients with endometrial cancer. Neoplasma 2004;51(3):193-197

24. Santin AD, Bellone S, Marizzoni M. Overexpression of claudin-3 and claudin-4 receptors in uterine serous papillary carcinoma: novel targets for a type-specific therapy using Clostridium perfringens enterotoxin (CPE). Cancer 2007;109(7):1312-1322

25. Schwartz PE. The management of serous papillary uterine cancer. Curr. Opin. Oncol. 2006;18(5):494-499

26. Hamilton CA, Cheung MK, Osann K. Uterine papillary serous and clear cell carcinomas predict for poorer survival compared to grade 3 endometrioid corpus cancers. Br. J. Cancer 2006; 94(5):642-646

27. Sood BM, Jones J, Gupta S. Patterns of failure after the multimodality treatment of uterine papillary serous carcinoma. Int. J. Radiation Oncol. Biol. Phys. 2003;57(1):208-216

28. Fader AN, Drake RD, O'Malley DM. Platinum/taxane-based chemotherapy with or without radiotherapy favorably impacts survival outcomes in stage I uterine papillary serous carcinoma. Cancer 2009;115(10):2119-2127

29. Sutton G, Axelrod JH, Bundy BN. Adjuvant whole abdominal irradiation in clinical stages I and II papillary serous or clear cell carcinoma of the endometrium: a Phase II study of the Gynecologic Oncology Group. Gynecol. Oncol. 2006;100(2):349-354

30. Huh WK, Powell M, Leath CA. Uterine papillary serous carcinoma: comparisons of outcomes in surgical stage I patients with and without adjuvant therapy. Gynecol. Oncol. 2003;91(3):470-475 